\title{
PROGRAM PENDIDIKAN PEMILIH DALAM MENINGKATKAN KUALITAS PARTISIPASI MASYARAKAT DAN REGULASI YANG MENGATURNYA DAN MALPRAKTIK DALAM PELAKSANAANNYA
}

\author{
Richardo F. Butarbutar 1), Jendrius 2), Ria Ariany3) \\ 1,2,3) Megister Kosentrasi Tata Kelola Pemilu Fakultas Ilmu Sosial Dan Ilmu Politik \\ Universitas Andalas, Padang, Indonesia
}

\begin{abstract}
Abstrak
Salah satu slogan atau tagline sosialisasi yang dikampanyekan KPU dalam mensukseskan Pemilu 2019 adalah "Pemilih Berdaulat Negara Kuat". Slogan tersebut dapat diartikan arti bahwa KPU mendorong peningkatan kualitas partisipasi masyarakat dalam pemilihan. Slogan tersebut menunjukkan kesadaran KPU bahwa pemilih memiliki peran strategis dan fundamental dalam membentuk lembaga eksekutif dan legislatif yang kapabel, kredibel, dan berintegritas. Karena itu pemilih dalam melaksanakan hak konstitusionalnya harus berdasarkan pada rasionalitas dan kesukarelaan. Pemilih harus berdaulat atas pilihannya dan tidak boleh tercederai oleh aspek-aspek primordialisme, pragmatis dan politik transaksional. Rasionalitas, kecerdasan, dan kemandirian pemilih menjadi sangat penting dalam peningkatan kualitas partisipasi masyarakat serta kualitas hasil pemilu. Dalam hal ini apakah regulasi yang ditetapkan dalam mengatur program kerja KPU sudah mencerminkan tujuannya dan bagaimana efektifitas program yang sedang dilaksanakan sehingga percepatan pencapaian tujuan tersebut dapat terealisasi dalam pelaksanaan pilkada serentak 2018 dan Pemilu 2019.
\end{abstract}

Kata Kunci : KPU, Pendidikan, Partisipasi

*Correspondence Address : miqbutar@gmail.com DOI : $10.31604 /$ jips.v6i2.2019.358-373

(C2019 Fakultas Keguruan \& Ilmu Pendidikan UM-Tapanuli Selatan 


\section{PENDAHULUAN}

Sejak masa kemerdekaan, Indonesia telah malaksanakan pemilu setidaknya 10 (sepuluh) kali dan pilkada sejak tahun 2005. Dalam kurun waktu tersebut telah banyak pembenahan dan perbaikan untuk kualitas penyelenggaraan pemilu dan pilkada. Peningkatan kualitas penyelenggaraan semestinya berdampak positif terhadap percepatan pembangunan, keadilan, kesejahteraan masyarakat, dan penjaminan terhadap hak-hak sipil warga negara yang menunjukkan kualitas demokrasi dalam aspek substansial. Namun yang terjadi adalah perkembangan yang terasa lambat jika dibandingkan dengan negara-negara maju lain yang kemerdekaan nya tidak jauh berbeda dengan masa kemerdekaan Indonesia.(The Economist Intelligence unit, 2018) Indonesia pada tahun 2017 berada pada peringkat 68 pada index demokrasi dunia yaitu sebanyak 25 tingkat dibawah Timor Leste sebagai negara baru yang baru lepas dari Indonesia. Hasil indeks demokrasi tersebut merupakan satu tamparan bagi wajah demokrasi Indonesia yang sudah lebih dulu berdemokrasi daripada Timor Leste. 20 (dua puluh) tahun Otonomi daerah belum mampu lahirkan kesejahteraan lokal juga belum mencapai tujuannya bahkan menunjukkan situasi dan kondisi dengan arah berbeda dari tujuan sebelumnya. KPU sebagai salah satu lembaga negara juga harus mampu mendorong percepatan pencapaian keberhasilan dalam aspek demokrasi substansial. Sesuai konsep dalam UUD 1945, KPU sebagai penanggungjawab penyelenggaraan pemilu seharusnya mampu membangun sebuah konsep nyata dan merealisasikannya dengan keberhasilan yang menunjukkan bahwa hasil pemilihan mendorong terciptanya lembaga eksekutif dan legislatif yang mampu menjawab persoalan-persoalan dalam pencapaian aspek demokrasi substansial.

Maraknya isu pluralisme yang mengancam keutuhan NKRI, isu hoax, praktek patronase sebagai kendala dan pemberantasan politik uang, politik transaksional, praktek oligarki, korupsi dan lain sebagainya masih menjadi penghambat kemajuan bangsa. Peran KPU seharusnya dapat dirasakan oleh masyarakat dalam hal ini. Menjadikan pemilih rasional, cerdas, dan mandiri menjadi sangat penting untuk dilaksanakan karena pemilih sebagai ujung tombak kedaulatan rakyat bertanggungjawab dalam memilih 
pemimpin yang mampu menyelesaikan persoalan bangsa.

Dalam pasal 449 Undang-undang Nomor 7 Tahun 2017 dan pasal 133 Undang-Undang Nomor 10 Tahun 2016 disebutkan bahwa pelaksanaan pendidikan politik bagi pemilih wajib mengikuti ketentuan yang diatur oleh KPU sementara KPU sepertinya belum memperhatikan program pendidikan pemilih sebagai program prioritas karena pengaturannya dalam PKPU tidak mudah untuk dipahami sehingga berdampak pada pencapaian outcome dari program tersebut.

KPU bekerja keras dalam meningkatkan kuantitas partisipasi masyarakat dalam pemilihan. Hal ini dapat dilihat dari target KPU dalam pelaksanaan pilkada serentak Tahun 2018 sebanyak 77,5 persen. Disisi lain KPU juga berharap bahwa peningkatan kuantitas partisipasi masyarakat juga harus seiring dengan peningkatan kualitas partisipasi masyarakat. Dalam hal ini dapat kita simpulkan bahwa program KPU untuk meningkatkan partisipasi adalah dengan pelaksanaan sosialisasi yang efektif dan untuk meningkatkan kualitas partisipasi masyarakat melalui program pendidikan pemilih. Pada titik inilah kelemahan program KPU terlihat, pelaksanaan sosialisasi diatur lebih rinci namun pelaksanaan pendidikan pemilih tidak diatur dengan jelas dan rinci sehingga konsep pendidikan pemilih yang mudah dipahami.

Kuantitas partisipasi masyarakat dapat dilihat dari kehadiran masyarakat di TPS (voter turn out) sedangkan kualitas partisipasi masyarakat dapat dilihat dari hasil pemilihan sampai dengan berakhirnya masa jabatan pejabat yang dipilih dalam pemilihan(Mardiniah, 2004). Kualitas hasil pemilihan menunjukkan kualitas demokrasi, apakah kualitas demokrasi mengalami peningkatan atau malah sebaliknya dan atau pada posisi stagnan. Secara umum kualitas hasil pemilihan dapat tercermin dari peserta pemilu yang terpilih, apakah calon yang memiliki latar belakang yang baik yang terpilih, apakah calon yang bebas korupsi yang terpilih, dan lain-lain, dan apakah selama masa pemerintahannya pejabat terpilih berupaya menunaikan janji-janjinya serta melaksanakan kewajibannya dengan penuh tanggung jawab. Salah satu instrumen yang dapat digunakan untuk meningkatkan kualitas hasil pemilihan adalah pendidikan pemilih, melalui pendidikan pemilih diharapkan pemilih mengerti dan paham hak dan kewajiban dalam 
pemilihan umum dan partisipasi dalam pemerintahan. Oleh karena itu pendidikan pemilih menjadi penting untuk dilaksanakan seoptimal mungkin.

Dalam Peraturan KPU tentang pelaksanaan pendidikan pemilih, disebutkan bahwa tujuan program pendidikan pemilih termasuk sosialisasi dan partisipasi masyarakat adalah pertama menyebarluaskan informasi mengenai tahapan, jadwal dan program Pemilu, kedua meningkatkan pengetahuan, pemahaman dan kesadaran masyarakat tentang hak dan kewajiban dalam Pemilu dan ketiga meningkatkan partisipasi Pemilih dalam pemilihan/Pemilu. Dalam poin pertama dan ketiga diatas cukup jelas diatur petunjuk pelaksanaanya dalam peraturan KPU yang mencakup materi sosialisasi, sasaran sosialisasi, metode sosialisasi sedangkan konsep pengaturan pendidikan pemilih hanya mencakup sasaran pendidikan pemilih. Poin kedua dalam meningkatkan pengetahuan, pemahaman, dan kesadaran masyarakat tentang hak dan kewajiban dalam pemilu merupakan tujuan khusus dalam pendidikan pemilih. Dalam hak dan kewajiban masyarakat tersirat nilai-nilai yang mesti dilaksanakan masyarakat dalam peningkatan kualitas pemilihan.
Secara umum meskipun pendidikan pemilih lebih untuk peningkatan kualitas partisipasi pemilu, pendidikan pemilih secara umum juga bertujuan untuk pertama meningkatkan kuantitas partisipasi pemilih. Merujuk pada Economist Inteligent Unit bahwa demokrasi yang mapan kuantitas partisipasi untuk memberikan suara berada pada kisaran 70\%. Partisipasi ini mesti dicatat sebagai bukan mobilisasi(Sigit Joyowardono, Titik Prihati Wahyuningsih, 2015). Angka partisipasi yang wajar ini penting karena menyangkut biaya pemilu yang mahal, legitimasi dan efektifitas kepemimpinan pejabat yang dipilih, serta eksistensi sistem demokrasi. Pelaksanaan pilkada tahun 2018 KPU menargetkan pencapaian kuantitas partisipasi bahkan sampai 77,5 persen pada tingkat nasional. Bicara partisipasi tentu bukan sekadar menjaga jumlah partisipasi agar terhindar dari angka kritis yang ditentukan berdasarkan standar internasional sebesar 70 persen dari jumlah pemilih di suatu negara tetapi partisipasi juga bicara soal kualitas.

Kedua pendidikan pemilih bertujuan untuk meningkatkan kemampuan literasi politik pemilih. Literasi politik merujuk pada 
kemampuan yang dibutuhkan pemilih untuk berpartisipasi dalam pemerintahan. Kemampuan dalam literasi pemilih meliputi pemahaman, keterampilan, dan perilaku yang menuntun pada partisipasi yang memperkuat sistem demokrasi. Kemampuan literasi politik dibutuhkan sebagai prayarat partisipasi politik yang ideal, baik selama periode pemilihan dan di luar periode pemilihan. Literasi politik yang baik menjadikan pemilih tahu bagaimana harus bersikap dan berpartisipasi dalam sebuah proses politik. Peminggiran kepentingan pemilih juga dapat dihindari dengan kemampuan literasi politik yang baik. Pemilih, dengan berbagai latar belakang akan paham bahwa berbagai proses politik sangat mempengaruhi kehidupannya. Tingkat literasi politik yang rendah menjadikan proses politik akan didominasi oleh segelintir orang. Kepentingan pemilih akan terpinggirkan dan rentan dimanipulasi. Dengan literasi politik yang baik akan terjadi saling keterpautan antara pemilih dengan proses politik (state and civil engagement).(Prof. Andi Faisal Bakti, 2014) dalam Literasi Politik dan Konsolidasi Demokrasi bahwa saat ini Indonesia masih berada dalam tahap transisi demokrasi dan berada jauh dari demokrasi. Hal ini terjadi karena masih terjadi banyak sumbatan akibat tidak adanya kesamaan agenda dan visi untuk konsolidasi demokrasi.

Ketiga pendidikan pemilih bertujuan untuk peningkatan kerelawanan. Pendidikan pemilih diharapkan mampu mendorong berkembangnya sikap kerelawanan pemilih dan mengikis sikap pragmatisme yang dianut oleh pemilih selama ini. Kerelawanan yang tumbuh baik dalam proses politik akan memperkuat bangunan demokrasi.

\section{PEMBAHASAN}

Program pendidikan pemilih yang saat ini sedang dilaksanakan KPU diantaranya adalah pertama sosialisasi pilkada serentak Tahun 2018, kedua sosialisasi pemilu Tahun 2019 yang ketiga pendidikan pemilih berbasis keluarga, keempat pembentukan relawan demokrasi, dan kelima pembentukan komunitas peduli pemilu dan demokrasi. Kelima program diatas pada pelaksanaannya terkesan hanya bertujuan untuk meningkatkan partisipasi masyarakat karena secara umum materi yang disampaikan dalam 5 (lima) kegiatan diatas belum menekankan pendidikan politik untuk meningkatkan literasi politik 
masyarakat tentang pentingnya rasionalitas, kemandirian, dan kesukarelaan dalam berpartisipasi pada pemilu atau pilkada. Penyampaian materi dan konsep tentang rasionalitas, kemandirian, dan kesukarelaan belum disampaikan secara efektif dan tidak menjadi perhatian utama. Sesuai regulasi yang mengatur, materi yang disampaikan masih berupa materi tahapan dan materi lain yang belum menyangkut peningkatan kualitas partisipasi dan kualitas demokrasi di Indonesia.

Kita tahu bahwa Pemilu dan Pilkada masih termasuk dalam aspek demokrasi prosedural dan belum menyentuh aspek demokrasi substansial. Kedua aspek ini saling terkait dan tidak dapat dipisahkan. Jika aspek demokrasi substansial dapat dicapai tanpa aspek prosedural atau sebaliknya maka nilai-nilai luhur demokrasi tidak dapat dicapai yang biasanya mempengaruhi pemenuhan atas jaminan hak-hak asasi manusia dalam implementasinya. Pendidikan pemilih bertujuan untuk mendorong pencapaian tujuan dalam demokrasi substansial serta merupakan salah satu langkah dalam mewujudkannya melalui nilai-nilai dan tujuan dalam demokrasi prosedural. Sempat muncul wacana pemilihan kepala daerah dipilih kembali oleh DPRD yang kemudian dieksekusi oleh pemerintah melalui Perppu Nomor 1 Tahun 2014. Wacana ini muncul disebabkan oleh hasil pemilihan yang tidak menunjukkan kualitasnya dan tidak mampu menyelesaikan persoalan klasik dalam pemerintahan didaerah sebelum penyelenggaraan pilkada langsung dilakukan sejak tahun 2005. Mau tidak mau persoalan yang tidak selesai tersebut dapat dikaitkan dengan kemampuan pemilih dalam menentukan pilihannya dan minimnya literasi politik pemilih sehingga tidak tahu bahwa sebagai pemilih, masyarakat juga seharusnya ikut mengawasi jalannya pemerintahan, yang terjadi masyarakat hanya meminta bagian materi atau non materi dalam politik transaksional dan ikut merusak system pemerintahan didaerah demi kepentingan pribadi dan kepentingan kelompok. Pendidikan pemilih jika dilaksanakan secara efektif dan diterima masyarakat dapat berdampak pada penguatan partisipasi masyarakat dalam pengawasan pemerintah. Penolakan masyarakat atas pemilihan kepala daerah oleh DPRD juga langsung dieksekusi oleh pemerintah dengan kembali mengeluarkan UndangUndang Nomor 1 Tahun 2015 tentang pemilihan kepala daerah. Penolakan 
tersebut muncul dari berbagai kelompok dan lapisan masyarakat. (Fahmi, 2016) Pemilihan secara langsung layak dipertahankan karena tidak ada jaminan pemilihan oleh DPRD tidak akan diwarnai oleh politik uang dan proliferasi perilaku korup oleh kepala daerah terpilih. Bukankah dengan pemilihan oleh DPRD, kepala daerah potensial terjebak dalam menghambakan diri dibawah hasrat kekuasaan segelintir elit yang ada di DPRD. Bukankah bangsa Indonesia telah berpengalaman selama puluhan tahun dalam rezim orde baru dimana kepala daerah yang terpilih berbau kolusi, korupsi, dan nepotisme?

(Budiman, 2017)Salah satu program pendidikan pemilih yang sedang dilaksanakan oleh KPU RI adalah pendidikan pemilih berbasis keluarga. Program ini dilaksanakan dalam menghadapi pilkada serentak 2018 dan akan dilakukan secara berkelanjutan. Pedoman pelaksanaan program ini diatur dalam surat edaran KPU RI Nomor 682/PP.08-SD/06/KPU/XI/2017 perihal pedoman pelaksanaan sosialisasi dan pendidikan pemilih berbasis keluarga tanggal 14 Nopember 2017. Dalam pedoman tersebut diatur tujuan, sasaran, konsep, materi, dan metode yang digunakan dalam pelaksanaannya.
Dalam pedoman tersebut dapat dianalisis bahwa antara metode dengan materi pendidikan pemilih ada kesenjangan konsep yang dapat menghambat keberhasilan program ini dalam pencapaian tujuannya. Pertama metode kegiatan melibatkan petugas pemutakhiran data pemilih dan KPPS yang waktu kerjanya sangat terbatas dimana pada masa pencalonan dan masa kampanye mengalami kekosongan waktu yang yang dapat digunakan oleh KPPS dan PPDP. Kedua KPPS dan PPDP tidak dijamin memiliki literasi politik yang cukup untuk menyampaikan materi pendidikan pemilih. Ketiga adalah sebagian besar materi yang disampaikan adalah materi sosialisasi yang telah dilaksanakan banyak pihak sehingga menimbulkan tumpang tindih kewenangan pelaksanaan sosialisasi, dan keempat adalah metode door to door sambil melakukan tanggung jawab sebagai PPDP dan KPPS cukup menyulitkan mereka dan memakan waktu.Artinya bahwa program yang sedang dilaksanakan KPU ini masih perlu pengembangan lebih lanjut dan dimodifikasi sehingga pelaksanaannya lebih efektif dan sederhana.

Pemanfaatan media hiburan seperti televisi, radio, media sosial/internet dalam pendidikan 
pemilih merupakan salah satu instrumen pendidikan yang efektif apalagi jika media tersebut merupakan media hiburan yang digunakan masyarakat sehari-hari. Penggunaan televisi sebagai instrument pendidikan pemilih memang kurang efisien karena biayanya mungkin terlalu mahal. KPU RI dapat mengefektifkan penggunaan media sosial yang lebih efisien dengan konsep dan strategi khusus yang dapat diterima masyarakat. KPU RI melalui jajarannya di Kabupaten/Kota dapat membentuk basis-basis pendidikan pemilih pada setiap daerah melalui media sosial atau internet agar kegiatan pendidikan pemilih dapat menjangkau lebih banyak pemilih pada basis-basis kabupaten/kota. Selama ini penggunaan media sosial oleh Kabupaten/Kota dirasa belum mencapai sasarannya karena dalam beberapa pengamatan konten-konten yang dimuat dalam media sosial kurang menarik dan tidak memuat materi pendidikan pemilih yang lebih banyak. Konten yang dimuat masih berupa sosialisasi kegiatan-kegiatan yang dilakukan oleh KPU Kabupaten/Kota dan sosialisasi tahapan pemilu.(Dr. Ir. Fayakhun Andriadi, 2017)menjelaskan bahwa hadirnya teknologi digital tidak Cuma merevolusi strategi komunikasi politik tetapi juga cara partisipasi politik warga negara. Sifat terbuka dan interaktif yang ada pada internet berpotensi untuk meningkatkan partisipasi politik. mereka terpacu untuk berpartisipasi karena alat untuk melakukan partisipasi lebih mudah, efektif, dan tidak monoton. Pemanfaatan media sosial sebagai sarana baru partisipasi politik berdampak pada lahirnya tren demokrasi yang baru. Ketika sarana yang digunakan baru otomatis corak partisipasi nya juga menjadi baru. Di era teknologi digital ini biasanya disebut cyberdemocrasy.

Saat ini, Indonesia masih berada dalam tahap transisi demokrasi dan berada jauh dari demokrasi. Hal ini terjadi karena masih terjadi banyak sumbatan akibat tidak adanya kesamaan agenda dan visi untuk konsolidasi demokrasi. Beberapa sumbatan tersebut yaitu Pertama, terjadi sumbatan dalam kekuasaan eksekutif. Performa eksekutif masih mandul dan terbebani politik akomodasi dalam menjalankan perannya. Apa yang menjadi prioritasnya adalah koalisi yang terakomodir pada pos-pos kekuasaan, dan bukan zaken kabinet yang sesuai dengan kapasitas untuk mempersembahkan kinerja yang baik pada rakyat. Kedua, sumbatan dalam 
kekuasaan legislatif. Terjadi dominasi fungsi-fungsi legislatif dalam mengkontrol anggaran dan pembuatan kebijakan. Dominasi ini hanya memperhitungkan kepentingan diri, kelompok, transaksional dan manajemen konflik. Ketiga, sumbatan di bidang hukum. Masih kuatnya akar korupsi tertanam di lembaga-lembaga pemerintahan dari legislatif, yudikatif hingga eksekutif menjadikan penegakan hukum masih sangat lemah. Keempat Munculnya apatisme masyarakat akan politik membuat kalangan elite leluasa bergerak dan merencanakan 366okum366is untuk tetap duduk di tampuk kekuasaan. Perlu ada penyadaran dan penguatan berbasis masyarakat yang akan melahirkan masyarakat yang memiliki perhatian, khususnya pada politik.(Prof. Andi Faisal Bakti, 2014)Literasi menjadi upaya yang penting bagi penguatan basis pengetahuan politik warga negara dan menghilangkan apatisme. Sehingga warga negara dapat berperan aktif untuk mewujudkan demokrasi yang lebih sehat dan berkualitas. Semakin cepat warga negara tercerahkan maka akan semakin memperbesar rasio masyarakat berperhatian. Karena kelompok masyarakat berperhatian ini biasanya turut menentukan nasib bangsa.

Literasi politik pemilih hanya dapat ditingkatkan dengan konsep pendidikan pemilih yang efektif. Memberikan pemahaman kepada pemilih bahwa melek politik merupakan hal yang wajib diketahui oleh setiap warga negara karena politik tak dapat dipisahkan dalam kehidupan bernegara setiap harinya. Masyarakat harus benarbenar sadar bahwa kehidupannya sangat dipengaruhi keputusankeputusan politik lokal, nasional, maupun internasional. Keputusankeputusan tersebut tertuang dalam peraturan perundang-undangan yang bersifat memaksa dan tidak peduli keputusan itu diterima dengan baik oleh masyarakat atau tidak. Tanpa partisipasi politik masyarakat yang aktif dalam pengawasan kekuasaan legislatif dan eksekutif, kesewenang-wenangan dan penyalahgunaan kekuasaan berpeluang besar untuk terjadi dan berakibat tidak baik bagi masyarakat.(Budiarjo, 2008) menyimpulkan bahwa politik dalam suatu negara berkaitan dengan masalah kekuasaan, pengambilan keputusan, dan alokasi atau distribusi.Dengan pengetahuan politik yang cukup maka harapannya adalah masyarakat mampu menjadi pemilih yang aktif 
berpartisipasi dalam pemilu dan mengedepankan rasionalitas, kemandirian, dan kerelawanan. Konsep kemandirian, rasionalitas, dan kerelawanan mampu meningkatkan kualitas hasil pemilu dan masyarakat tidak mudah untuk diprovokasi dan dimobilisasi dengan isu-isu primordial yang memecah belah, isu hoax sebagai kampanye hitam, dan kepentingan kelompok-kelompok tertentu yang seolah-olah berpihak kepada rakyat namun sesungguhnya hanya merupakan gaya politik murahan sebagaimana yang sering ditampilkan oleh kebanyakan pejabat-pejabat yang tidak produktif dan tidak berintegritas.(Kenney, 2004)Dengan isu hoax dan kampanye hitam nilai-nilai demokrasi akan turun yang ditandai dengan apatisme masyarakat terhadap demokrasi. Isu hoax dan kampanye negative lebih mudah untuk diterima oleh masyarakat daripada kampanye positif. Orientasi pilihan mestinya sedemikian rupa didasarkan pada kepentingan bangsa dan negara secara umum dan kesejahteraan masyarakat secara khusus.

Tahap awal dari pendidikan pemilih akan berfokus pada mekanisme dan jadwal waktu pemilu-pemilu, serta himbauan agar para pemilih berpartisipasi mengingat rendahnya pengetahuan mereka tentang hal-hal tersebut. Di tahap awal ini, harus disampaikan secara langsung pada seluruh pemilu semua hal menyangkut kapan pemilu dilangsungkan dan lembaga-lembaga apa yang akan dipilih, prosedur pemilu, termasuk bagaimana memberikan suara dan bagaimana para pemenang akan ditentukan, tenggat waktu pendaftaran pemilih, danProsedur pengaduan masalahmasalah pemilu. Tahap kampanye ini harus dilakukan sesegara mungkin, mengingat rendahnya tingkat pengetahuan mereka tentang pemilu serta jadwal pemilu yang makin dekat. Di samping itu, pesan-pesan tertentu harus diarahkan pada kelompok sasaran khusus pemilih.

Tahap kedua dari pelaksanaan pendidikan pemilih akan berusaha untuk memberikan lebih banyak kesempatan pada para pemilih untuk mempelajari apa-apa saja yang dapat mereka harapkan dari partai politik dan lembaga-lembaga perwakilan, membandingkan para kontestan, dan menyuarakan keinginan pada mereka. Tahap ini akan menyasar seluruh pemilih, mengingat rendahnya tingkat pemahaman mereka terhadap peran lembaga-lembaga perwakilan serta 
perbedaan di antara partai-partai politik. Salah satu bagian dari Tahap kedua ini adalah kampanye informasi pada 368okum368, yang berisi pesanpesan untuk meningkatkan harapan para pemilih kepada para kandidat mereka serta lembaga-lembaga yang akan dipilih. Pesan-pesan itu akan memberitahukan pemilih mengenai Bagaimana mereka dapat menggunakan kampanye untuk tujuan instrumental dan media ekspresi: dengan menyuarakan pandangan mereka terhadap berbagai isu, menuntut kebijakan serta sumber-sumber daya yang mereka inginkan, mendukung para kandidat yang pandanganpandangannya mereka setujui, dan menarik mundur pejabat yang tidak mereka setujui, Apa yang dapat dilakukan oleh para anggota DPR dan kemudian apa yang dapat dituntut para pemilih pada mereka, mengekspresikan pandangan-pandangan para pemilih, membuat undang-undang, mengganti kebijakan, membantu mereka memecahkan masalah dengan pemerintahan, menanyai para menteri, mendapatkan sumberdaya, dan sebagainya. Bagian lain dari fase kedua ini adalah untuk memperkuat keterkaitan antara para pemilih dan para kontestan. Ini harus terdiri dari upaya-upaya non-partisan untuk membantu para pemilih menemukan dan membandingkan pemikiran partaipartai politik serta para kandidat berkaitan dengan isu-isu yang sangat penting dari kacamata pemilu. Hal ini, termasuk Pertemuan-pertemuan yang memfasilitasi pemilih untuk menanyai para kandidat dari partai-partai yang berbeda dan media yang nonpartisan untuk memberikan perbandingan pernyataan dari partai-partai yang berbeda mengenai masalah yang sedang dihadapi. Kampanye ini harus diadakan pada saat kampanye pemilu untuk pemilihan sedang berjalan dan pada saat tahap pertama telah mampu memberikan informasi-informasi dasar tentang pemilu.(Martinelli, 2005) menyebutkan bahwa pemilih yang mendapatkan cukup informasi maka akan mempengaruhi pemilih lain yang tidak mendapatkan informasi yang cukup. Pemerataan penyebaran informasi menjadi penting dalam hal ini. Tahap ketiga dari pelaksanaan pendidikan pemilihadalah pendidikan kewarganegaraan yang memfokuskan pada promosi nilai-nilai demokrasi dan toleransi pada sektor-sektor penduduk yang pemahamannya terhadap nilainilai ini masih relatif lemah. Pesanpesan untuk mempromosikan nilai-nilai 
demokrasi, harus mendiskusikan hal-hal berikut, yaitu karakter dan arti dari demokrasi, prinsip-prinsip utama demokrasi, mendorong perempuan untuk menentukan pilihannya sendiri, dan mendorong terjadinya diskusidiskusi mengenai politik. Pesan-pesan yang bertujuan meningkatkan toleransi politik diharapkan bisa membangun sikap toleran terhadap pertemuanpertemuan yang diselenggarakan oleh partai yang tidak disenangi dan sikap toleran terhadap kandidat dari kelompok yang sering mendapat perlakuan diskriminatif.

Pendidikan pemilih dibutuhkan untuk menjelaskan perubahanperubahan yang telah terjadi di dalam sistem pemilu, dengan demikian pemilih bisa memahami bagaimana sistemnya akan bekerja, di samping untuk mempromosikan persaingan pemilu berlandaskan isu, sehingga pemilih bisa merasa bahwa mereka bisa melakukan perubahan. Pendidikan warga negara haruslah beranjak dari hal-hal yang paling mendasar, makna demokrasi, otonomi politik perempuan, dan toleransi terhadap partai lainnya. Harus pula dimasukkan topik-topik seperti prinsip-prinsip demokratis serta penerimaan terhadap kandidat dari kelompok yang tidak disenangi.
(Meisburger, 2003)Prioritas pendidikan pemilih di Indonesia semestinya bukan lagi membangun kredibilitas proses pemilu, namun untuk mempromosikan konsolidasi demokrasi dalam konteks ketika pemilu yang bebas merupakan fakta yang sudah ada.

Pada akhirnya pendidikan pemilih ini memang terlihat mengarah kepada pendidikan moral pemilih. Namun dalam konteks yang luas, pendidikan pemilih jangan sampai terkesan mendikte atau menggurui pemilih dalam memutuskan pilihannya. Konsep, materi, dan strategi pendidikan pemilih harus sedemikian rupa dirumuskan agar tidak menimbulkan persoalan baru dalam kehidupan berdemokrasi. Jika seperti pendidikan moral kepada pemilih, dapat menimbulkan sikap antipati dari masyarakat, khususnya masyarakat yang tidak mengedepankan rasionalitas dalam preferensi politiknya karena sebagian masyarakat Indonesia masih ada yang mengedepankan identitas dansosiologis tertentu dalam memutuskan preferensi politiknya.

$$
\text { Pada sebuah penelitian yang }
$$
meneliti terkait perilaku memilih di Eropa mengkaji tentang pilihan pemilih antara kompetensi dan kejujuran menyimpulkan bahwa pemilih 
mengedepankan pilihannya pada kejujuran yang dapat dirasakan daripada kejujuran yang dikampanyekan(Fabio Galeotti a, 2018). Dengan maraknya politik uang, isu pluralism, politik transaksional, dan korupsi menunjukkan bahwa masyarakat Indonesia tidak terlalu menekankan kejujuran, kompetensi, dan kinerja seseorang dalam menentukan pilihannya. KPU sebagai penyelenggara pemilu semestinya dapat menemukan konsep, materi, dan strategi dalam pelaksanaan pendidikan pemilih agar masyarakat menekankan integritas, kompetensi dan kinerja dalam pendidikan pemilih. Pemilih Indonesia diarahkan kearah yang benar dalam tujuan bersama sebagai bangsa dan negara. Harus dapat disadari bahwa sebagai bangsa yang besar, perilaku memilih pemilih memiliki peran dalam menjaga keutuhan dan kestabilan politik di Indonesia. Tanpa keutuhan dan kestabilan politik,status Indonesia sebagai bangsa yang besar terancam.

Dua puluh tahun reformasi belum menunjukkan hasil yang memuaskan jika dibandingkan perkembangan pada negara-negara lain. Bahkan sudah banyak pihak-pihak yang ingin melakukan reformasi kembali atas ketidakpuasan hasil yang dicapai. Suka tidak suka perkembangan yang lambat tentu ada hubungannya dengan kualitas penyelenggaraan pemilu yang berdampak pada kualitas pejabatpejabat yang terpilih dalam pemilu. Pemilu dengan pemilih yang secara rasional tidak tahu di mana keberhasilan reformasi terkait dengan kompetensi seorang politisi yang tidak dapat diobservasi menunjukkan bahwa permintaan pemilih untuk tingkat reformasi yang tinggi tetapi tidak diiringi dengan kemampuan pemilih untuk mengobservasi dalam memutuskan pilihannya. Pemilih sering terjebak pada isu populisme yang mengusulkan agenda reformis namun pemilih tidak mengobservasi kemampuan mereka untuk berhasil melaksanakannya. Karena keterbatasan kemampuan pemilih dalam mengobservasi, para pemilih kemudian dihadapkan pada salah satu reformis beresiko atau kelambanan kebijakan.Hubungan antara permintaan untuk reformasi dan kemungkinan perubahan kebijakan apapun yang bersifat terbaru dan bersifat kerakyatan diimplementasikan tergantung pada bagaimana reformasi gagal yang berbahaya. Pada akhirnya kemungkinan untuk munculnya agenda reformasi kembali dapat terjadi atas dampak krisis 
dalam perkembangan yang lambat. Kebangkitan populisme dapat menyebabkan kekecewaan politik daripada kepuasan masyarakat(Carlo Prato, 2017).

Efek dari permintaan yang tinggi terhadap kemungkinan reformasi, disisi lain, tergantung pada kekuatan perhatian pemilih dalam pemilihan. Ketika kompetensi seorang politisi sangat penting bagi keberhasilan reformasi, kemungkinan reformasi menurun (baik tidak ada kandidat yang melakukan agenda reformis, atau pemilih secara nasional menunjukkan skeptisisme yang tinggi terhadap mereka yang melakukannya, dan memilih mereka dengan probabilitas rendah). Sebaliknya, ketika kekhawatiran pemilihan permintaan reformasi yang lebih rendah meningkatkan kemungkinan reformasi, tetapi hal ini memiliki risiko yang signifikan. Keseimbangan yang memaksimalkan kesejahteraan menunjukkan suatu bentuk populisme rasional dimana beberapa kandidat mengusulkan reformasi meskipun tidak berhasil memberlakukannya (Carlo Prato, 2017).

\section{KESIMPULAN}

Konsep pendidikan pemilih yang diatur dalam regulasi setidaknya memuat tujuan pendidikan yang menanamkan nilai-nilai yang berkaitan dengan pemilu dan demokrasi dalam kehidupan berbangsa dan bernegara kepada warganegara yang telah memenuhi syarat sebagai pemilih dalam pemilu atau potensial memilih dalam rentang waktu kemudian. Nilai-nilai dalam demokrasi paling pokok dalam pelaksanaan pemilu adalah nilai kesetaraan hak politik setiap warga negara. Kesetaraan hak politik warga negara terancam dalam demokrasi apabila isu primordialisme, praktek patronase, politik uang, politik transaksional mewarnai kehidupan demokrasi. Bahkan alangkah baiknya jika konsep yang dibangun dalam materi pendidikan pemilih juga dapat mencerdaskan pemilih sehingga mampu terlibat aktif dalam pengawasan dalam masa jabatan pejabat terpilih melalui partisipasi masyarakat dalam pemerintahan.

Upaya KPU dalam meningkatkan kuantitas partisipasi pemilih setidaknya harus seimbang dengan upaya dalam meningkatkan kualitas partisipasi masyarakat dalam pemilu. Bahkan sebenarnya menjadikan peningkatan 
kualitas partisipasi masyarakat menjadi program prioritas KPU RI adalah hal yang lebih penting karena peningkatan kualitas partisipasi berarti peningkatan kualitas demokrasi,mengingat kuantitas partisipasi merupakan hasil dari mobilisasi politik ataupun mobilisasi penyelenggara yang sering sekali tanpa disertai oleh kerelawanan pemilih. Pemilih yang berdaulat adalah pemilih yang rasional, cerdas, dan mandiri. Dengan konsep pemilih berdaulat, pendidikan pemilih harus dilakukan dengan konsep pendidikan yang sama dengan tujuan pendidikan formal lainnya yaitu menanamkan nilai-nilai positif yang dapat diimplementasikan demi kebaikan bersama dalam hidup berbangsa dan bernegara dan dilaksanakan terus menerus hingga nilai-nilai yang diinginkan dapat tertanam dalam sikap dan perilaku pemilih. Program pendidikan pemilih yang efektif adalah program yang dilakukan dengan profesional dan pertimbangan-pertimbangan hukum sehingga program ini dapat dilaksanakan oleh banyak pihak seperti partai politik, pemerintah, institusi pendidikan, dan organisasi masyarakat dengan orientasi kepada pencapaian percepatan pemilih Indonesia menjadi rasional, cerdas, mandiri, dan
sukarela.Program pendidikan pemilih harus dilaksanakan dengan konsep dan strategi yang dapat diukur tingkat keberhasilannya. Program pendidikan pemilih dilakukan secara bertahap dan berkesinambungan. Komitmen KPU untuk ikut mendorong terlaksananya pemerintahan yang kompeten dan kapabel dapat dilakukan dengan program pendidikan pemilih yang efektif.

Dengan pendidikan pemilih, praktik politik uang yang menumbuhkan sikap pemilih yang pragmatis dapat diberantas, klientanisme dan patronase yang mengikis kemandirian pemilih dapat diredam, mampu menangkal hoax dan kampanye hitam, dan mampu meningkatkan partisipasi masyarakat dalam pengawasan pemerintahan. Keterlibatan masyarakat dalam pengawasan pemerintahan dapat mencegah penyalahgunaan kekuasaan, mempercepat program pembangunan, dan membantu pemerintah dalam pengambilan keputusan-keputusan strategis.

\section{Daftar Pustaka}

Budiarjo, P. M. (2008). Dasar-Dasar Ilmu Politik. Jakarta: Gramedia Pustaka Utama.

Budiman, A. (2017). Pedoman Sosialisasi dan Pendidikan Pemilih Berbasis Keluarga. Jakarta: KPU RI. 
Carlo Prato, S. W. (2017). Rational Ignorance, Populism, and Reform. European Journal of Political Economy, 1.

Diamond, L. (2003). Developing Democracy Toward Consolidation. Yogyakarta: IRE Press Yogyakarta.

Dr. Ir. Fayakhun Andriadi, M. (2017). Partisipasi Politik Virtual. Jakarta: RMBOOKS.

Fabio Galeotti a, D. J. (2018). Identifying voter preferences: The trade-offbetween honesty and competence. Elsevier, 49.

Fahmi, K. (2016). Pemilihan Umum Dalam Transisi Demokrasi. Padang: Raja Grafindo Persada.

Holli A. Semetko, M. S. (2016). Handbook Komunikasi Politik. Bandung: Nusa Media.

Kenney, K. L. (2004). Dampak Kampanye Negatif Pada Tindakan dan Sikap Warga. American political science review, 317.

Mardiniah, N. (2004). Memperkuat posisi politik rakyat. Jakarta: CESDA-LP3ES.

Martinelli, C. (2005). Would rational voters acquire costly information? Journal of economic theory, 2.

Meisburger, T. (2003). Demokrasi in Indonesia. In R. B. Douglas Ramage, Sebuah Survei Pemilih Indonesia 2003 (p. 195). Jakarta: The Asia Foundation.

Nam-Jin, J. M. (2006). Jaringan Sosial, diskusi publik dan keterlibatan kewarganegaraan; Perspektif Sosialisasi. Political Communication, 376.

Prof. Andi Faisal Bakti, P. D. (2014). Literasi Politik dan Konsolidasi Demokrasi . Jakarta: The Policy Institute.

Sigit Joyowardono, Titik Prihati Wahyuningsih. (2015). Buku Pedoman Pendidikan Pemilih. Jakarta: KPU RI.

The Economist Intelligence unit. (2018). Democration Index 2017. In Free Speech Attack (p. 6). London. 